THURSDAY, MARCH $20, \quad 1884$

\section{A BIOLOGICAL LABORATORY ON THE ENGLISH COAST}

A

RRANGEMENTS have been made for a meeting in the rooms of the Royal Society at half-past four, on Monday, March 3I, the object of which is to found a Society having for its purpose the establishment and maintenance of a well-equipped laboratory at a suitable point on the English coast, similar to, if not quite so extensive as, Dr. Dohrn's Zoological Station at Naples.

The value of such an institution to the progress of zoological science, and the simple necessity which exists for the thorough and detailed knowledge only to be gained by the constant work of a well-supported laboratory devoted to the complete exploration of a definite area of sea-bottom, if any reasonable action is to be taken in regulating and improving British sea fisheries, have been set forth at various times in these pages during the past year in connection with the conferences held at the Fisheries Exhibition.

English naturalists have at length determined to do their best to bring about the foundation of the desired laboratory. A large sum of money will be needed in order to secure a site and erect the necessary buildings, besides the provision of an annual income. The Society will be able to raise these funds and to administer them in a more satisfactory way than would be possible were the matter taken in hand by a few private individuals only. The laboratory, when once set going, together with its boats and fishermen, will be used for the purpose of carrying on investigations by any naturalists who are members of the Society, and may desire from time to time to avail themselves of its resources. Its work will therefore be chiefly carried on by volunteers, and it is quite certain that there are a very large number of thoroughly competent naturalists who are only waiting for the opportunity thus afforded. At present such men are to be found scattered here and there on our coasts, making shift to carry on observations without laboratory, boats, or any efficient appliances. Eventually it will no doubt be possible to place a qualified observer in charge of the laboratory. The laboratory will also be available for special investigations, for which a public body or other autbority may have employed the services of a naturalist.

Apart from the conveniences which it can afford and the value of the moral effect of combined action even in scientific investigation-the continuous working of a number of naturalists at one spot has a most important reaction upon their work. In proportion as a particular area becomes thoroughly familiar in this way, it becomes easy to obtain special animals and plants for study which were at first regarded as rare, or were altogether unknown in the locality. The thorough and long-continued operations of such a laboratory have naturally enough the value of systematised work as compared with the casual dippings and exploratory incursions of the isolated naturalist who spends a month in one year at this place and a month in another year at another place.

VOL. XXIX.-No. $75 \mathrm{I}$
Already in Scotiand, on the Firth of Forth, close to Edinburgh-through the admirable energy of Mr. John Murray, the director of the Challenger Expedition publications-a small laboratory has been set up, and funds obtained for carrying on its work by the engagement of young naturalists to investigate special problems. The English laboratory will be erected at a point as rich as possible in respect of its marine fauna, and at the same time in proximity to important fishing grounds. No locality has yet been decided upon, but both Torquay and Weymouth have been suggested as presenting the desired combination. Everything depends on the amount of pecuniary support which the Society will be able to obtain. A great work may be done if sufficient funds are forthcoming; a smaller work will be accomplished with smaller funds, and carried on in the firm expectation of gaining increased means of activity as results are produced justifying the enterprise.

But as a matter of fact, no tentative method of procedure is needed. It is quite certain, from the experience obtained in other countries, that a properly provided observatorywith good working-rooms, large and small tanks, seawater pump, a steam launch and well-trained fishermen and permanent staff-can turn out results which are numerous and valuable in proportion to the completeness of the arrangements and the experience of the permanent staff. France was the first country to start such marine laboratories or observatories. At present there are several in operation on the French coast-viz. at Roscoff, at Concarneau, at Villefranche, and near Cette. Italy boasts of the great international laboratory founded and carried on with wonderful perseverance and success by Dr. Dohrn at Naples. An jdea of the cost of a really first-rate institution of the kind may be gathered from the fact that the palatial building in the Villa Nazionale at Naples with its fittings and fishing-boats represents a capital of $20,000 l$., whilst the annual expenditure is over $4000 l$. Austria has such a laboratory at Trieste, maintained by the Imperial Government. Among the most successful of such laboratories have been those established on the eastern coast of the United States. That at Beaufort, directed by the Johns Hopkins University, has furnished an extraordinary amount of interesting results through the activity of Mr. Brooks and the young naturalists of the United States who make use of it. That erected by Prof. Alexander Agassiz at Newport (Maine) is no less satisfactory as an evidence of the utility of such institutions. Since the found ation of these laboratories (within the past decade) our knowledge of marine organisms has increased at an enormous $r$ ate : without them we should have gone on in the casual, uncertain way which necessarily arose from the fact that every naturalist, before the foundation of these laboratories, had to establish his own little workshop for the summer and to make a fresh start in an unexplored locality, or in one explored only by the efforts of himself alone.

The meeting on March 3I promises to be one of great influence. Prof. Huxley, P.R.S., is to preside. Prof. Flower, Prof. Moseley, Prof. Milnes Marshall, Sir Lyon Playfair, Mr. W. S. Caine, M.P. (one of the Commission on Trawling), Prof. Michael Foster, Prof. Ray Lankester, Dr. Albert Günther, Dr. W. B. Carpenter, Mr. Gwyn Jeffreys, Dr. P. L. Sclater, Mr. Frank Crisp, Sir John 
Lubbock, and other gentlemen, have signified their intention of being present and supporting the resolutions which are to be submitted to the meeting.

We beg to refer those of our readers who are interested in this subiect to the articles published during the past year in NATURE, and to the arguments advanced in support of the proposal to found such a laboratory, together with a sketch of the relation of zoological science to the wellbeing of British fisheries, in the address on the Scientific Results of the Fisheries Exhibition delivered by Prof. Ray Lankester at the conference on July 19, and published by the Exhibition Committee.

\section{THE UNITY OF NATURE}

The Unity of Nature. By the Duke of Argyll. (London: Strahan, 1884.)

THIS book is in our judgment a dreary failure. 1 Although in the mere matter of style it is a well written popular exposition of what we may call the comfortable way of looking at things, in all matters of deeper importance it is utterly barren. Throughout its five or six hundred pages there is no single original observation in science, nor any single original thought in anything that deserves to be called philosophy. Moreover, if regarded only as an exposition, the first chapters are tedious on account of the redundant manner in which elementary science is explained, while the later chapters, in which the author's views on various philosophical questions are unfolded, display a feebleness of thought and argument which renders them even more tedious than the earlier ones. In short, the successive essays strongly remind us of a series of Scottish sermons. There is cverywhere a narrow consistency in the doctrine, which is presented in a rhetorical precision of style; but the discussion never seems to get below the surface, while even surface difficulties are either unperceived or intentionally avoided. On this account the discussion itself tends to illustrate the principle of "unity" with which it is concerned; it begins, continues, and ends in a monotone. No matter how fearfully out of tune this may be with any of the notes struck by the greatest men of our time, the Duke of Argyll, like a Highland piper, is deaf to every other music, and drowns all else in the one continuous drone of his own particular instrument.

The pages of a scientific journal are not suited to an examination in any detail of the parts of the book to which these general remarks apply. We shall, therefore, proceed to examine the more purely scientific strands which are woven into the texture of the wor's. In this connection the chief topic which meets us is that of "Animal Instinct in Relation to the Mind of Man." Here the main question which is dealt with-that as to the mode of origin and development of instincts-appears to us most inefficiently treated. The object of the writer is to argue that the phenomena of instinct point directly to the design of a Creator, who correlates instinct with structure and environment. So far, of course, every evolutionist, who is also a theist, may go. But, in order to enforce this view, the Duke proceeds to argue that the phenomena in question are of so mysterious a nature that it is not possible to point to any causes of a proxi- mate or physical kind which may reasonably be supposed to produce them. Now it would be easy to show-were this the place to show it-that the writer has here adopted a weak position even as an apologist; but, to consider the matter only from the side of science, surely it shows some grave want either of judgment or of consideration to make the kind of statements of which the following may be taken as fair examples :-

"I can therefore see no light in this new explanation to account for the existence of instincts which are certainly antecedent to all individual experience-the explanation, namely, that they are due to the experience of progenitors 'organised in the race.' It involves assumptions contrary to the analogies of nature, and at variance with the fundamental facts, which are the best, and indeed the only, basis of the theory of evolution. There is no probability- there is hardly any possibility-in the supposition that experience has had, in past times, some connection with instinct which it has ceased to have in the present day. ... There was a time when animal life, and with it animal instincts, began to be. But we have no reason whatever to suppose that the nature of instinct then or since has ever been different from it; niture now. On the contrary, as we have in nature examples of it in infinite variety, from the very lowest to the very highest forms of organisation, and as the same phenomena are everywhere repeated, we have the best reason to conclude that, in the past, animal instinct has ever been what we now see it to be-congenital, innate, and wholly independent of experience."

Such passages as these scarcely admit of comment, because all that can be said about them is that the writer has either never read, or has completely forgotten, the whole of the literature to which he alludes. No evolutionist has ever entertained the suicidal "supposition that experience has had, in past times, some connection with instinct which it has ceased to have in the present day;" and the conclusion that in the absence of so absurd a supposition the only alternative is to regard instinct as always having been wholly independent of experience is a conclusion which stands in direct opposition to all that constitutes "evolution" a "theory." Of course no one is bound to accept this theory; it may be rejected, or it may be left unmentioned; but it is futile to set up a nonsensical form of words, and then to call the absurdity the "theory of evolution."

And these are no mere chance expressions, which, if standing alone, might be indicative only of carelessness. The whole of the dissertation on instinct is pervaded by a similar misapprehension, or want of apprehension, of the fundamental ideas of the newer philosophy which the writer appears to suppose that he is considering. Thus, he fails to perceive that the doctrine of natural selection has any bearing upon the subject, while, with reference to the factor of what Mr. Darwin called "inherited habit," he says :- -

"If the habits and powers which are now purely innate and instinctive were once less innate and more deliberate, then it will follow that the earlier faculties of animals have been higher, and that the later faculties are the lower in the scale of intelligence. This is hardly consistent with the accepted idea of evolution," \&c.

Comment is needless. We shall, therefore, notice only one other point with reference to the essay on instinct, 